\title{
Pengaruh Dana Pihak Ketiga, Loan to Deposit Ratio dan Non Performing Loan Terhadap Jumlah Penyaluran Kredit Pada Bank Umum di Bursa Efek Indonesia
}

\author{
Muhammad Firdaus ${ }^{1}$, Ninin Non Ayu Salmah ${ }^{2}$ \\ ${ }^{1}$ Fakultas Ekonomidan Bisnis Universitas PGRI Palembang \\ ${ }^{2}$ Fakultas Ekonomi dan Bisnis Universitas PGRI Palembang, nininonayu@gmail.com
}

\begin{abstract}
ABSTRAK
Penelitian ini bertujuan untuk mengetahui pengaruh dana pihak ketiga, loan to deposit ratio dan non performing loan terhadap jumlah penyaluran kredit pada Bank Umum di Bursa Efek Indonesia. Data yang diamati berupa laporan keuangan tahun 2016, 2017 dan 2018. Analisis data yang digunakan yaitu statistik inferensial dengan teknik analisis regresi linear berganda dan pengujian hipotesis. Hasil penelitian ini adalah 1)secara simultan dana pihak ketiga, loan to deposit ratio dan non performing loan berpengaruh signifikan terhadap jumlah penyaluran kredit pada Bank Umum di Bursa Efek Indonesia; 2)secara parsial dana pihak ketiga berpengaruh signifikan terhadap jumlah penyaluran kredit pada Bank Umum di Bursa Efek Indonesia; 3) secara parsial loan to deposit ratio berpengaruh signifikan terhadap jumlah penyaluran kredit pada Bank Umum di Bursa Efek Indonesia dan 4)secara parsial loan to deposit ratio berpengaruh tidak signifikan terhadap jumlah penyaluran kredit pada Bank Umum di Bursa Efek Indonesia.
\end{abstract}

Kata Kunci: dana pihak ketiga, loan to deposit ratio, non performing loan, jumlah penyaluran kredit

\begin{abstract}
This study aims to determine the effect of third party funds, loan to deposit ratio and non performing loan on the amount of lending to commercial banks on the Indonesia Stock Exchange. The data observed were in the form of financial reports for 2016, 2017 and 2018. The data analysis used was inferential statistics with multiple linear regression analysis techniques and hypothesis testing. The result of this study are 1)simultaneous, third party funds, loan to deposit ratio and non performing loan have a significant effect on the amount of lending to commercial banks on the Indonesia Stock Exchange; 2) partially, third party funds has a significant effect on the amount of lending to commercial banks on the Indonesia Stock Exchange; 3)loan to deposit ratio has a significant effect on the amount of lending to commercial banks on the Indonesia Stock Exchange and 4)non performing loan has no a significant effect on the amount of lending to commercial banks on the Indonesia Stock Exchange.
\end{abstract}

Keywords : third party funds, loan to deposit ratio, non performing loan, the amount of lending

\section{A. PENDAHULUAN}

Perbankan merupakan lembaga yang memegang peranan penting dalam perekonomian karena perbankan menyediakan jasa yang dibutuhkan oleh nasabah. Undang- undang RI No 10 tahun 1998 tanggal 10 November 1998 tentang Perbankan menyatakan bank merupakan badan usaha yang menghimpun dana dari masyarakat dalam bentuk simpanan dan menyalurkannya kepada masyarakat dalam bentuk kredit dan bentuk lainnya dalam rangka meningkatkan taraf hidup rakyat banyak.

Bank dibedakan atas bank sentral, bank umum dan bank perkreditan rakyat. Bank umum adalah bank yang melaksanakan kegiatan usaha secara konvensional maupun berdasarkan prinsip syariah, yang dalam kegiatannya memberikan jasa dalam lalu lintas pembayaran. Bank merupakan bagian dari industri jasa keuangan dengan sebagian besar perusahaan perbankan telah terdaftar di Bursa Efek Indonesia dalam sektor keuangan subsektor bank. 
Investor menilai kinerja perbankan melalui analisis variabel fundamental perbankan diantaranya dicerminkan melalui penyaluran kredit yang dilakukan bank sehingga dapat mendukung suatu perekonomian Indonesia. Bank melakukan kebijakan kredit melalui beberapa variabel diantaranya dana pihak ketiga (DPK), loan to deposit ratio (LDR), non performing loan (NPL).

Fahmi (2014:82) menjelaskan dana pihak ketiga merupakan sumber dana yang berasal dari masyarakat sebagai nasabah dalam bentuk simpanan giro, tabungan dan deposito. Sumber dana pihak ketiga merupakan sumber dana terpenting bagi kegiatan operasi bank dan merupakan tolak ukur keberhasilan suatu bank jika mampu membiayai operasinya dari sumber dana ini. Pencairan dana dari sumber ini relatif paling mudah jika dibanding sumber dana lainnya dan penarikan dana dari sumber ini tidak terlalu sulit sehingga mempermudah pihak yang berkepentingan.

LDR merupakan rasio keuangan yang digunakan untuk mengukur komposisi kredit yang diberikan dibandingkan dengan jumlah dana masyarakat dan modal sendiri. Likuiditas perbankan perlu dikelola guna memenuhi kebutuhan saat nasabah mengambil dananya dan menyalurkan kredit kepada peminjam. Jika nilai LDR terlalu rendah, berarti perbankan memiliki likuiditas yang cukup memadai tetapi mungkin pendapatan lebih rendah karena seperti yang diketahui dunia perbankan memperoleh pendapatan melalui kredit yang disalurkan.

Fahmi (2014:100) menjelaskan NPL merupakan kredit yang dikategorikan dalam tiga kualitas yaitu kredit dengan kualitas yang kurang lancar, kredit dengan kualitas yang diragukan dan kredit macet. Hal tersebut berarti NPL merupakan indikasi tentang adanya masalah dalam bank tersebut, yang apabila tidak segera diatasi maka akan berdampak pada penyaluran kredit untuk periode berikutnya.

Berkaitan dengan pengaruh DPK, LDR dan NPL terhadap jumlah penyaluran kredit pada Bank yang terdaftar di Bursa Efek Indonesia maka tujuan dari penelitian ini adalah untuk mengetahui 1)signifikansi pengaruh DPK, LDR dan NPL terhadap jumlah penyaluran kredit pada Bank Umum di Bursa Efek Indonesia secara simultan; 2)signifikansi pengaruh DPK terhadap jumlah penyaluran kredit pada Bank Umum di Bursa Efek Indonesia secara parsial; 3)signifikansi pengaruh LDR terhadap jumlah penyaluran kredit pada Bank Umum di Bursa Efek Indonesia secara parsial dan 4)signifikansi pengaruh NPL terhadap jumlah penyaluran kredit pada Bank Umum di Bursa Efek Indonesia secara parsial.

\section{B. Kajian Teori \\ Dana Pihak Ketiga}

Hendro dan Rahardja (2014:125) menyimpulkan dana pihak ketiga merupakan kegiatan membeli dana dari masyarakat dengan imbalan berupa bunga simpanan. Kasmir (2016:59) mendefinisikan dana pihak ketiga sebagai sumber dana terpenting bagi kegiatan operasional bank dan merupakan ukuran keberhasilan bank jika mampu membiayai operasionalnya dari sumber dana ini. Dana pihak ketiga merupakan sumber dana yang paling dominan dibanding sumber dana lainnya.

Sumber dana pihak ketiga meliputi 1)simpanan giro, giro adalah sebagai sejumlah dana yang disimpan disuatu perbankan dan dana tersebut dapat ditarik berdasarkan permintaan seseorang dimana penarikannya itu biasanya dapat dilakukan dengan mengunakan cek atau bilyet giro, dana giro ini dapat diambil kapan saja berdasarkan keinginan pihak yang bersangkutan (Fahmi, 2014:87); 2)simpanan tabungan, tabungan mempunyai syarat syarat tertentu bagi pemegangnya dan persyaratan setiap bank berbeda satu sama lainnya (Kasmir, 2016:69); dan 
3)simpanan deposito, deposito merupakan simpanan yang mengandung unsur jangka waktu (jatuh tempo) lebih panjang dan tidak dapat ditarik setiap saat atau setiap hari (Kasmir, 2016:74).

\section{Loan to Deposit Ratio}

Kasmir (2016:319) menjelaskan loan to deposit ratio merupakan rasio untuk mengukur komposisi jumlah kredit yang diberikan dibanding dengan jumlah dana masyarakat dan modal sendiri yang digunakan. Rasio ini dapat dijadikan patokan apakah bank masih dapat melakukan ekspansi terhadap pinjamannya atau harus membatasinya. Namun yang terjadi jika rasio LDR ini terlampau kecil yang artinya bahwa jumlah kredit yang disalurkan juga sedikit, hal ini akan berimbas pada bank yang akan kesulitan dalam menutup simpanan nasabahnya.

Jika bank mempunyai LDR yang sangat tinggi, maka bank akan mempunyai risiko tidak tertagihnya pinjaman yang tinggi pada titik tertentu bank akan mengalami kerugian. Oleh karena itu Bank Indonesia sebagai bank sentral telah memberikan standar untuk rasio LDR perbankan di Indonesia, yaitu pada kisaran antara $85 \%$ sampai dengan $100 \%$. Dengan demikian jika rasio LDR yang dimiliki oleh bank terlalu tinggi ataupun terlalu rendah maka bank tersebut akan mengalami kesulitan dalam meningkatkan labanya.

\section{Non Performing Loan}

Non performing loan diatur dalam Surat Keputusan Direktur Bank Indonesia Nomor 31/147/KEP/DIR tahun 1998. Dalam surat keputusan tersebut kredit digolongkan menjadi lima, yaitu lancar, dalam perhatian khusus, kurang lancar, diragukan, dan macet. Non performing loan merupakan tingkat kolektibilitas kredit yang dianggap bermasalah dan dapat mengganggu kegiatan operasional inilah yang disebut dengan kredit macet. NPL diungkapkan melalui persentase dengan kriteria kurang lancar, diragukan, dan macet terhadap total kredit yang disalurkan. Bank Indonesia telah menetapkan ketentuan NPL sebesar 5\%. Apabila bank mampu menekan rasio NPL dibawah 5\%, maka potensi keuntungan yang akan diperoleh akan semakin besar, karena bank-bank akan menghemat uang yang diperlukan untuk membentuk cadangan kerugian kredit bermasalah.

\section{Kredit}

Undang-undang Perbankan No 10 Tahun 1998 menjelaskan kredit adalah penyediaan uang atau tagihan yang dapat dipersamakan dengan itu, berdasarkan persetujuan atau kesepakatan pinjam meminjam antar bank dengan pihak lain yang mewajibkan pihak peminjam melunasi hutangnya setelah jangka waktu tertentu dengan pemberian bunga. Seseorang atau suatu badan yang memberikan kredit (kreditor) percaya bahwa penerima kredit (debitur) pada masa yang akan datang akan sanggup memenuhi segala sesuatu yang telah dijanjikan, berupa barang, uang atau jasa. Kasmir (2016:96), menyimpulkan kredit merupakan uang atau tagihan yang diukur dengan uang dan adanya kesepakatan antar bank dengan nasabah penerima kredit yang didalamnya tercakup hak dan kewajiban masing-masing pihak, termasuk jangka waktu serta bunga.

Abdullah (2017:165) menjelaskan unsur-unsur yang terkandung dalam pemberian kredit adalah 1)kepercayaan, yaitu suatu keyakinan pemberian kredit bahwa kredit yang diberikan akan benar-benar diterima kembalu di masa yang akan datang; 2)kesepakatan, meliputi kesepakatan antara si pemberi kredit dengan si 
penerima kredit; 3)jangka waktu, setiap kredit yang diberikan memiliki jangka waktu tertentu, jangka waktu ini mencakup masa pengembalian kredit yang telah disepakati; 4)risiko, adanya suatu tenggang waktu pengembalian akan menyebabkan suatu risiko tidak tertagihnya kredit; dan 5)balas jasa, merupakan keuntungan atas pemberian suatu kredit, balas jasa dalam bentuk bunga.

\section{Prinsip Pemberian Kredit}

Abdullah (2017:172) menjelaskan sebelum suatu fasilitas kredit diberikan maka bank harus merasa yakin bahwa kredit yang diberikan benar-benar akan kembali. Kriteria penilaian yang harus dilakukan oleh bank untuk mendapatkan nasabah yang benar-benar menguntungkan dilakukan dengan 5C yaitu 1)character, suatu keyakinan bahwa sifat atau watak dari orang-orang yang akan diberikan kredit benarbenar dapat dipercaya yang dapat dilihat dari latar belakang pekerjaan nasabah; 2) capacity, untuk melihat kempuan nasabah dalam bidang bisnis yang dihubungkan dengan pendidikannya maupun kemampuan bisnisnya; 3)capital, untuk melihat penggunaan modal secara efektif dari laporan keuangan; 4)collateral, merupakan jaminan yang diberikan calon nasabah baik bersifat fisik maupun non fisik dan 5)condition, dalam menilai kredit hendaknya dinilai kondisi ekonomi sekarang dan kemungkinan untuk masa yang akan datang sesuai sektor masing-masing.

\section{Bank Umum}

Undang Undang Perbankan No. 10 Tahun 1998 mendefinisikan bank sebagai suatu badan usaha yang menghimpun dana dari masyarakat dalam bentuk simpanan dan menyalurkannya kepada masyarakat dalam bentuk kredit atau bentukbentuk lainnya dalam rangka meningkatkan taraf hidup orang banyak. Bank adalah suatu lembaga yang berperan sebagai perantara keuangan antara pihak-pihak yang memiliki kelebihan dana dengan pihak-pihak yang memerlukan dana serta sebagai lembaga yang memperlancar lalu lintas pembayaran.

\section{Bursa Efek Indonesia}

Hendro dan Rahardja (2014:349) menyimpulkan Bursa Efek Indonesia adalah pihak yang menyediakan sarana untuk mempertemukan penawaran jual beli efek dengan tujuan memperdagangkan efek. BEI bersifat self regulatory organization agar mampu menciptakan perdagangan efek yang teratur, wajar, khususnya yang berkaitan dengan keanggotaan bursa, perdagangan dan pencatatan efek.

\section{Pengajuan Hipotesis}

Hipotesis yang diajukan dalam penelitian ini adalah 1)secara simultan dana pihak ketiga, loan to deposit ratio dan non performing loan berpengaruh signifikan terhadap jumlah penyaluran kredit pada Bank Umum di Bursa Efek Indonesia; 2) )secara parsial dana pihak ketiga berpengaruh signifikan terhadap jumlah penyaluran kredit pada Bank Umum di Bursa Efek Indonesia; 3)secara parsial loan to deposit ratio berpengaruh signifikan terhadap jumlah penyaluran kredit pada Bank Umum di Bursa Efek Indonesia dan 4)secara parsial non performing loan berpengaruh signifikan terhadap jumlah penyaluran kredit pada Bank Umum di Bursa Efek Indonesia. 


\section{METODE PENELITIAN}

Metode penelitian ini adalah kuantitatif. Noor (2015:2) menjelaskan metode kuantitatif sebagai metode yang menguji teori-teori tertentu dengan cara melihat hubungan antar variabel, variabel-variabel ini diukur sehingga data yang terdiri dari angka-angka dapat dianalisis.

\section{Objek Penelitian}

Objek penelitian ini adalah Bank Umum yang terdaftar di Bursa Efek Indonesia dengan periode pengamatan 2016 sampai dengan 2018, penelitian dilakukan di Bursa Efek Indonesia (BEI) melalui website https://www.idx.co.id.

\section{Variabel Penelitian dan Definisi Operasional Variabel}

Bahri (2018:130) menjelaskan variabel penelitian merupakan salah satu komponen penelitian yang berkaitan dengan proses penelitian secara komprehensif. Variabel dalam penelitian adalah 1) variabel independen dalam penelitian ini yaitu dana pihak ketiga, loan to deposit ratio dan non performing loan dan 2) variabel dependen yaitu jumlah penyaluran kredit.

Definisi operasional variabel dalam penelitian ini adalah 1) dana pihak ketiga, didefinisikan sebagai penjumlahan giro, tabungan dan deposito; 2) loan to deposit ratio, merupakan sebagai pembagian jumlah kredit yang disalurkan dengan dana pihak ketiga; 3) non performing loan, merupakan sebagai pembagian jumlah kredit bermasalah dengan jumlah kredit yang disalurkan; dan 4) jumlah kredit yang disalurkan yang didefinisikan sebagai uang atau tagihan yang diukur dengan uang dan adanya kesepakatan antar bank dengan nasabah penerima kredit yang didalamnya tercakup hak dan kewajiban masing-masing pihak, termasuk jangka waktu serta bunga.

\section{Populasi dan Sampel}

Sujarweni (2014:90) menyatakan populasi yaitu wilayah generalisasi yang terdiri atas objek/subjek yang mempunyai kualitas dan karateristik tertentut yang ditetapkan oleh penelliti dan kemudian ditarik kesimpulan. Populasi dalam penelitian ini adalah semua Bank Umum yang terdaftar di Bursa Efek Indonesia periode tahun 2016 sampai dengan tahun 2018 yang berjumlah 43 Bank.

Bahri (2018:51) menjelaskan sampel merupakan sebagian dari populasi yang diambil melalui cara-cara tertentu yang juga memiliki karakteristik tertentu. Pemilihan sampel dalam penelitian ini menggunakan metode purposive sampling yang memilih sampel berdasarkan kriteria tertentu sehingga diperoleh informasi yang maksimal. Kriteria yang digunakan untuk menentukan sampel dalam penelitian ini adalah 1). Perusahaan merupakan Bank Umum dan terdaftar di Bursa Efek Indonesia selama periode pengamatan dan 2). Bank Umum tersebut mempublikasikan laporan keuangan selama periode pengamatan yaitu tahun 2016 sampai dengan tahun 2018. Berdasarkan kriteria tersebut maka jumlah sampel yang memenuhi kriteria untuk menjadi sampel sebanyak 28 Bank Umum dengan jumlah observasi sebanyak 84 data.

\section{Sumber dan Teknik Pengumpulan Data}

Data dalam penelitian ini menggunakan data sekunder. Data sekunder adalah data yang diperoleh secara tidak langsung dan melalui media perantara, berasal dari sumber-sumber yang telah ada atau data sudah tersedia dan dikumpulkan oleh pihak lain (Bahri, 2018:81-82).

Sanusi (2014:105) menjelaskan teknik pengumpulan data adalah cara yang dapat digunakan peneliti untuk mengumpulkan data. Teknik pengumpulan data 
dalam penelitian ini adalah dokumentasi dengan mengumpulkan data berupa laporan keuangan tahunan yang dipublikasikan selama periode pengamatan yaitu tahun 2016, 2017 dan 2018.

\section{Teknik Analisis Data}

Sujarweni (2014:74) menyatakan bahwa teknik analisis data ialah cara melaksanakan analisis data dengan tujuan pengolaan data tersebut untuk menjawab rumusan masalah. Teknik analisis data dalam penelitian adalah statistik inferensial dengan alat analisis data meliputi uji asumsi klasik, analisis regresi berganda, dan pengujian hipotesis dengan uji $\mathrm{F}$ dan uji t. Proses pengolahan data untuk penelitian ini menggunakan software SPSS for windows.

\section{Uji Asumsi Klasik}

Analisis regresi linier berganda didahului uji asumsi klasik yang meliputi uji normalitas, uji normalitas, uji heteroskedastisitas dan uji autokorelasi. Model regresi mempersyaratkan data berdistribusi normal, tidak terjadi gejala multikolinearitas, heteroskedastisitas dan autokorelasi.

Uji normalitas digunakan untuk mengetahui apakah data berdistribusi normal atau tidak. Uji normalitas dalam penelitian ini dilakukan dengan metode one-sample Kolmogorov-Smirnov dengan ketentuan jika nilai Asymp. Sig. (2-tailed) lebih dari 0,05 maka data dikatakan berdistribusi normal.

Uji multikolinearitas digunakan untuk mengetahui terjadi atau tidaknya korelasi diantara variabel bebas. Uji multikolinearitas dalam penelitian ini dilakukan dengan melihat nilai VIF (variance inflation factors) dan tolerance dengan ketentuan jika nilai VIF lebih kecil dari 10,00 dan atau jika nilai tolerance lebih besar dari 0,10 maka dikatakan tidak terjadi gejala multikolinearitas.

Uji heteroskedastisitas digunakan untuk mengetahui apakah terjadi heteroskedatisitas dalam model regresi. Uji heteroskedastisitas dalam penelitian ini dilakukan dengan scatter plot dengan ketentuan jika titik-titik dalam diagram menyebar di atas dan di bawah angka pada sumbu $X$ maka dikatakan tidak terjadi gejala heteroskedastisitas.

Uji autokorelasi digunakan untuk mengetahui korelasi antara anggota observasi yang disusun menurut waktu dan tempat. Uji autokorelasi dalam penelitian ini dilakukan dengan melihat nilai dari Durbin Watson (DW) dengan ketentuan nilai DW sebesar -2 $\leq \mathrm{DW} \leq 2$ maka dikatakan tidak terjadi autokorelasi.

\section{Analisis Regresi Linear Berganda}

Analisis regresi linear berganda digunakan untuk mengetahui pengaruh variabel independen terhadap variabel dependen. Persamaan regresi linear berganda adalah $Y=a+b_{1} X_{1}+b_{2} X_{2}+b_{3} X_{3}$ dimana $Y$ adalah variabel dependen jumlah penyaluran kredit, $\mathrm{X}_{1}$ adalah variabel independen dana pihak ketiga, $\mathrm{X}_{2}$ adalah variabel independen loan to deposit ratio, $\mathrm{X}_{3}$ adalah variabel independen non performing loan, a adalah konstanta, $b_{1}$ adalah koefisien regresi dengan variabel independen dana pihak ketiga, $b_{2}$ adalah koefisien regresi dengan variabel independen loan to deposit ratio dan dan $b_{3}$ adalah koefisien regresi dengan variabel independen non performing loan.

\section{Uji Hipotesis}

Uji hipotesis dilakukan dengan uji simultan (uji F) dan uji parsial (uji t). Uji $F$ digunakan untuk pengujian hipotesis dimana variabel-variabel independen yang dimasukkan dalam model berpengaruh secara simultan terhadap variabel dependen. Kriteria pengambilan keputusan dalam uji $\mathrm{F}$ adalah jika nilai signifikansi $\leq 0,05$ maka 
$\mathrm{H}_{0}$ diterima yang berarti secara simultan variabel independen berpengaruh tidak signifikan terhadap variabel dependen sebaliknya jika nilai signifikansi $\geq 0,05$ maka $\mathrm{H}_{0}$ ditolak dan $\mathrm{H}_{a}$ diterima yang berarti secara simultan variabel independen berpengaruh terhadap variabel dependen.

Uji statistik $\mathrm{t}$ digunakan untuk pengujian hipotesis dimana variabel-variabel independen yang dimasukkan dalam model berpengaruh secara parsial terhadap variabel dependen. Kriteria pengambilan keputusan dalam uji t adalah jika nilai signifikansi $\leq 0,05$ maka $\mathrm{H}_{0}$ diterima yang berarti secara parsial variabel independen berpengaruh tidak signifikan terhadap variabel dependen sebaliknya jika nilai signifikansi $\geq 0,05$ maka $\mathrm{H}_{0}$ ditolak dan $\mathrm{H}_{\mathrm{a}}$ diterima yang berarti secara parsial variabel independen berpengaruh terhadap variabel dependen.

\section{HASIL PENELITIAN}

\section{Uji Asumsi Klasik}

Hasil uji normalitas dengan metode One-Sample Kolmogorov-Smirnov disajikan pada tabel berikut ini.

Tabel Hasil Uji Normalitas

\begin{tabular}{|c|c|c|}
\hline \multirow{2}{*}{\multicolumn{2}{|c|}{$\mathrm{N}$}} & Unstandardized Residual \\
\hline & & 84 \\
\hline \multirow[t]{2}{*}{ Normal Parameters ${ }^{a}$} & Mean & 0.0000000 \\
\hline & Std. Deviation & 0.00318606 \\
\hline \multirow[t]{3}{*}{ Most Extreme Differences } & Absolute & 0.146 \\
\hline & Positive & 0.065 \\
\hline & Negative & -0.146 \\
\hline \multicolumn{2}{|l|}{$\begin{array}{l}\text { Kolmogorov-Smirnov Z } \\
\text { Asvmo Sia. (2-tailed) }\end{array}$} & 1.342 \\
\hline Asymp. Sig. (2-tailed) & & 0.054 \\
\hline
\end{tabular}

Tabel di atas menunjukkan nilai Asymp. Sig. (2-tailed) sebesar 0,054 atau lebih besar dari 0,05 maka dapat disimpulkan data berdistribusi normal dan data dapat digunakan dalam model regresi. ini.

Hasil uji heteroskedastisitas dengan Scatter Plot disajikan pada gambar berikut

\section{Gambar Hasil Uji Heteroskedastisitas}

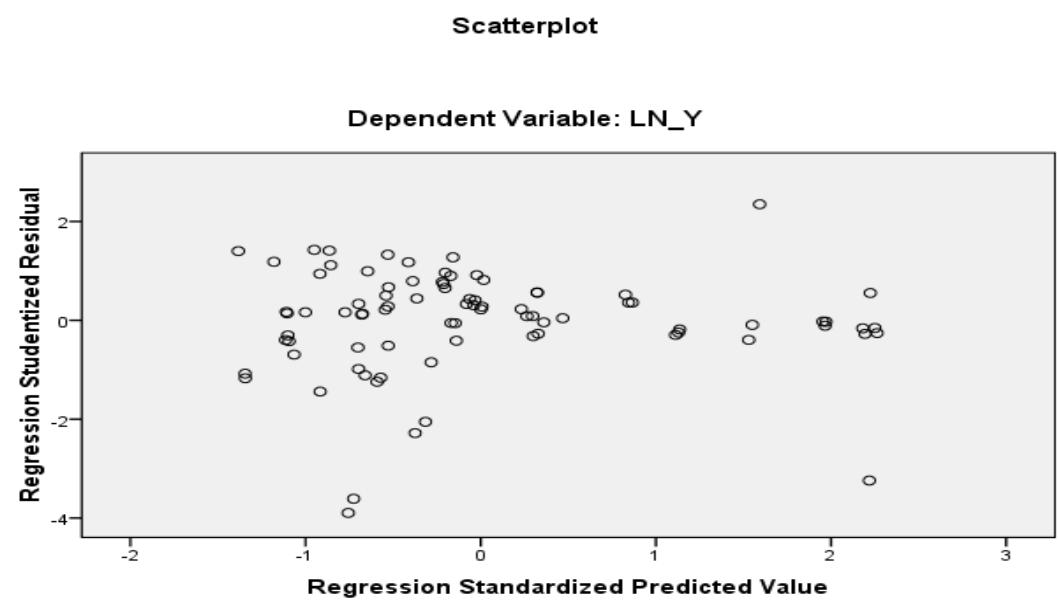


Gambar di atas menunjukkan titik-titik menyebar di atas dan di bawah angka 0 dan dan tidak membentuk pola tertentu sehingga dapat disimpulkan bahwa tidak terjadi heterokedastisitas dan data dapat digunakan dalam model regresi.

Hasil uji multikolinearitas dengan melihat nilai VIF dan nilai tolerance disajikan pada tabel berikut ini.

Tabel Hasil Uji Multikolinearitas

\begin{tabular}{|c|c|c|}
\hline Variabel & Tolerance & VIF \\
\hline Dana Pihak Ketiga & .989 & 1.011 \\
\hline Loan to Deposit Ratio & .964 & 1.037 \\
\hline Non Performing Loan & .973 & 1.028 \\
\hline
\end{tabular}

Tabel di atas menunjukkan nilai VIF pada DPK sebesar 1,011, pada LDR sebesar 1,037, dan VIF pada NPL sebesar 1,028 serta nilai tolerance pada DPK sebesar 0,989, pada LDR sebesar 0,964 dan NPL sebesar 0,973. Nilai VIF kurang dari 10 dan tolerance lebih dari 0,10 memberi kesimpulan tidak terjadi gejala multikolinieritas dan data dapat digunakan dalam model regresi.

Hasil uji autokorelasi menggunakan uji Durbin Watson (DW) disajikan pada tabel berikut ini.

Tabel Hasil Uji Autokorelasi

\begin{tabular}{|l|c|}
\hline \multicolumn{1}{|c|}{ Variabel } & DW \\
\hline Dana Pihak Ketiga & 1.724 \\
\hline Loan to Deposit Ratio & 0.477 \\
\hline Non Performing Loan & 0.476 \\
\hline
\end{tabular}

Tabel di atas menunjukkan nilai DW DPK sebesar 1.724, LDR sebesar 0.477, NPL sebesar 0.476 masing-masing terletak diantara -2 sampai +2 memberikan kesimpulan tidak terjadi autokorelasi sehingga data dapat digunakan dalam model regresi.

\section{Analisis Regresi Linear Berganda}

Tabel berikut ini menyajikan output regresi linear berganda dari variabelvariabel yang terlibat dalam penelitian.

Tabel Hasil Regresi Linear Berganda

\begin{tabular}{|l|c|}
\hline \multicolumn{1}{|c|}{ Variabel } & Nilai \\
\hline Konstanta a & .027 \\
\hline Dana Pihak Ketiga & 1.008 \\
\hline Loan to Deposit Ratio & .039 \\
\hline Non Performing Loan & .002 \\
\hline
\end{tabular}

Tabel di atas memperlihatkan persamaan regresi linier berganda sebagai berikut $Y=0,027+1,008 X 1+0,039 X 2+0,002 X 3$. Nilai konstanta a sebesar 0,027 berarti tanpa adanya variabel DPK, LDR dan NPL maka jumlah penyaluran kredit sebesar 0,027 satuan.

Koefisien regresi dengan variabel independen DPK sebesar 1,008 berarti jika DPK naik sebanyak 1 satuan, maka jumlah penyaluran kredit pada Bank Umum di Bursa Efek Indonesia akan meningkat sebesar 1,008 satuan dan sebaliknya jika 
DPK turun sebanyak 1 satuan, maka jumlah penyaluran kredit pada Bank Umum di Bursa Efek Indonesia akan menurun sebesar 1,008 satuan, sementara itu LDR dan NPL konstan. Koefisien regresi dengan variabel independen LDR sebesar 0,039 berarti jika LDR naik sebanyak 1 satuan maka jumlah penyaluran kredit pada Bank Umum di Bursa Efek Indonesia akan meningkat sebesar 0,039 satuan dan sebaliknya jika LDR turun sebanyak 1 satuan, maka jumlah penyaluran kredit pada Bank Umum di Bursa Efek Indonesia akan menurun sebesar 0,039 satuan sementara itu DPK dan NPL konstan. Koefisien regresi dengan variabel independen NPL sebesar 0,002 berarti jika NPL naik sebanyak 1 satuan, maka jumlah penyaluran kredit pada Bank Umum di Bursa Efek Indonesia akan meningkat sebesar 0,002 satuan dan sebaliknya jika DPK turun sebanyak 1 satuan, maka jumlah penyaluran kredit pada Bank Umum di Bursa Efek Indonesia akan menurun sebesar 0,002 satuan sementara itu DPK dan LDR konstan.

\section{Uji Hipotesis}

Tabel berikut ini menyajikan hasil uji hipotesis secara simultan dengan uji $\mathrm{F}$ dengan variabel independen DPK, LDR dan NPL dan variabel dependen jumlah penyaluran kredit.

Tabel Hasil Uji F

\begin{tabular}{|l|c|c|}
\hline \multicolumn{1}{|c|}{ Variabel } & Signifikan & $\boldsymbol{\alpha ( 0 , 0 5 )}$ \\
\hline $\begin{array}{l}\text { Dana Pihak Ketiga, } \\
\text { Loan to Deposit Ratio, dan } \\
\text { Non Performing Loan }\end{array}$ & 0.005 & 0,05 \\
\hline
\end{tabular}

Berdasarkan tabel di atas diperoleh nilai signifikan sebesar 0,005 atau lebih kecil dari 0,05 maka disimpulkan $\mathrm{H}_{0}$ ditolak dan $\mathrm{H}_{a}$ diterima yang berarti secara simultan DPK, LDR, dan NPL berpengaruh signifikan terhadap jumlah penyaluran kredit pada Bank Umum di Bursa Efek Indonesia.

Tabel berikut ini menyajikan hasil uji hipotesis secara parsial dengan uji $t$ dengan variabel independen DPK, LDR dan NPL dan variabel dependen jumlah penyaluran kredit.

Tabel Hasil Uji t

\begin{tabular}{|l|c|c|}
\hline \multicolumn{1}{|c|}{ Variabel } & Signifikan & $\mathbf{\alpha ~ ( 0 . 0 5 )}$ \\
\hline Dana Pihak Ketiga & .000 & 0,05 \\
\hline Loan to Deposit Ratio & .000 & 0,05 \\
\hline Non Performing Loan & .376 & 0,05 \\
\hline
\end{tabular}

Berdasarkan tabel di atas, uji t dengan variabel independen DPK diperoleh nilai signifikan sebesar 0,000 atau lebih kecil dari 0,05 maka disimpulkan $\mathrm{H}_{0}$ ditolak dan $\mathrm{H}_{\mathrm{a}}$ diterima yang berarti secara parsial DPK berpengaruh signifikan terhadap jumlah penyaluran kredit pada Bank Umum di Bursa Efek Indonesia. Uji t dengan variabel independen LDR diperoleh nilai signifikan sebesar 0,000 atau lebih kecil dari 0,05 maka disimpulkan $\mathrm{H}_{0}$ ditolak dan $\mathrm{H}_{a}$ diterima yang berarti secara parsial LDR berpengaruh signifikan terhadap jumlah penyaluran kredit pada Bank Umum di Bursa Efek Indonesia. Uji t dengan variabel independen NPL diperoleh nilai signifikan sebesar 0,376 atau lebih besar dari 0,05 maka disimpulkan $\mathrm{H}_{0}$ diterima yang berarti 
secara parsial NPL berpengaruh tidak signifikan terhadap jumlah penyaluran kredit pada Bank Umum di Bursa Efek Indonesia.

\section{E. PEMBAHASAN}

\section{Pengaruh DPK, LDR dan NPL terhadap Jumlah Penyaluran Kredit}

Hasil pengujian hipotesis dengan uji $F$ yang menyimpulkan secara simultan DPK, LDR, dan NPL berpengaruh signifikan terhadap jumlah penyaluran kredit pada Bank Umum di Bursa Efek Indonesia senada dengan penelitian Amelia dan Murtiasih (2017) yang menyatakan bahwa secara simultan variabel dana pihak ketiga, loan to deposit ratio dan non performing loan berpengaruh signifikan terhadap jumlah penyaluran kredit.

\section{Pengaruh DPK terhadap Jumlah Penyaluran Kredit}

Hasil pengujian hipotesis dengan uji t yang menyimpulkan secara parsial DPK berpengaruh signifikan terhadap jumlah penyaluran kredit pada Bank Umum di Bursa Efek Indonesia senada dengan penelitian Amelia dan Murtiasih (2017) serta Suryawati, Cipta dan Susila (2018) yang menyatakan bahwa variabel dana pihak ketiga berpengaruh signifikan terhadap jumlah penyaluran kredit tetapi berbeda dengan kesimpulan Febrianto dan Muid (2013) yang menyatakan bahwa variabel dana pihak ketiga tidak berpengaruh secara signifikan terhadap jumlah penyaluran kredit.

\section{Pengaruh LDR terhadap Jumlah Penyaluran Kredit}

Hasil pengujian hipotesis dengan uji t yang menyimpulkan secara parsial LDR berpengaruh signifikan terhadap jumlah penyaluran kredit pada Bank Umum di Bursa Efek Indonesia senada dengan penelitian Febrianto dan Muid (2013), Amelia dan Murtiasih (2017) serta Suryawati, Cipta dan Susila (2018) yang menyatakan bahwa loan to deposit ratio berpengaruh secara signifikan terhadap jumlah penyaluran kredit.

\section{Pengaruh NPL terhadap Jumlah Penyaluran Kredit}

Hasil pengujian hipotesis dengan uji t yang menyimpulkan secara parsial NPL berpengaruh tidak signifikan terhadap jumlah penyaluran kredit pada Bank Umum di Bursa Efek Indonesia senada dengan penelitian Febrianto dan Muid (2013) yang menyatakan bahwa non performing loan berpengaruh tidak signifikan terhadap jumlah penyaluran kredit tetapi berbeda dengan kesimpulan Suryawati, Cipta dan Susila (2018) yang menyatakan bahwa non performing loan berpengaruh signifikan terhadap jumlah penyaluran kredit.

\section{F. KESIMPULAN DAN SARAN}

1) Kesimpulan

Kesimpulan dari penelitian ini adalah 1) secara simultan dana pihak ketiga, loan to deposit ratio dan non performing loan berpengaruh signifikan terhadap jumlah penyaluran kredit pada Bank Umum di Bursa Efek Indonesia; 2)secara parsial dana pihak ketiga berpengaruh signifikan terhadap jumlah penyaluran kredit pada Bank Umum di Bursa Efek Indonesia; 3)secara parsial loan to deposit ratio berpengaruh signifikan terhadap jumlah penyaluran kredit pada Bank Umum di Bursa Efek Indonesia; dan 4)secara parsial non performing loan berpengaruh tidak signifikan terhadap jumlah penyaluran kredit pada Bank Umum di Bursa Efek Indonesia 


\section{2) Saran}

Penelitian ini menyarankan 1)bagi penguna laporan keuangan khususnya investor, masyarakat dan pihak internal bank yang terdaftar di Bursa Efek Indonesia hendaknya lebih memperhatikan lagi variabel dana pihak ketiga dan rasio-rasio keuangan perbankan diantaranya loan to deposit ratio dan non performing loan dalam mengambil keputusan; 2)bagi penelitian selanjutnya dapat menambahkan rasio keuangan bank lainnya sebagai variabel independen karena kemungkinan rasio keuangan yang tidak dimasukkan dalam penelitian ini berpengaruh terhadap jumlah penyaluran kredit.

\section{DAFTAR PUSTAKA}

Abdullah, Thamrin. (2017). Bank dan Lembaga Keuangan Edisi 1 Cetakan 4. Jakarta: PT RajaGrafindo Persada.

Amelia, Kharisma Citra dan Sri Murtiasih. (2017). Analisis Pengaruh DPK, LDR, NPL dan CAR Terhadap Jumlah Penyaluran Kredit Pada PT Bank Indonesia. Jurnal Ilmiah Ekonomi Bisnis, vol 22 no 1 hal 66-74.

Bahri, Syaiful. (2018). Metodologi Penelitian Bisnis Lengkap Dengan Teknik Pengelolahan Data SPSS.Yogyakarta: ANDI.

Fahmi, Irham. (2014). Bank dan Lembaga Keuangan Lainnya Teori dan Aplikasi. Bandung: Alfabeta.

Febriyanto, Dwi Fajar dan Dul Muid. (2013). Analisis Pengaruh Dana Pihak Ketiga, LDR, NPL, CAR, ROA, dan BOPO Terhadap Jumlah Penyaluran Kredit. Diponegoro Journal of Accounting, vol 2 no 4 hal 1-11.

Hendro, Tri dan Conny Tjandra Rahardja. (2014). Bank \& Institut Keuangan Non Bank Di Indonesia. Yogyakarta: UPP STIM YKPN.

Kasmir. (2016). Bank dan Lembaga Keuangan Lainnya. Jakarta: PT RajaGrafindo Persada.

Noor, Juliansyah. (2015). Metodologi Penelitian. Jakarta:CV Prrnadamedia Group.

Sanusi, Anwar. (2014). Metodologi Penelitian Bisnis Edisi Ke-4. Jakarta: Salemba Empat.

Sujarweni, V. Wiratna. (2014). Metodologi Penelitian. Yogyakarta: Pustaka Baru Perss.

Suryawati, Cipta dan Susila . (2018). Analisis Pengaruh Dana Pihak Ketiga (DPK), Capital Adequency Ratio (CAR), Non Performing Loan (NPL), dan Loan Tto Deposit Ratio (LDR) Terhadap Jumlah Penyaluran Kredit (Studi Pada LPD Desa Pakraman Pemaron). Bisma : Jurnal Manajemen, vol 4 no 1 hal 8-16.

Undang-undang Perbankan No 10 Tahun 1998 